\title{
İlk Okuma Yazma Öğretim Sürecine Veli Etkisinin Öğretmen Görüşlerine Göre İncelenmesi
}

\author{
Dr. Öğr. Üyesi Muhittin SAĞIRLI \\ İstanbul Üniversitesi-Cerrahpaşa, Hasan Âli Yücel Eğitim Fakültesi, Temel Eğitim Bölümü, \\ İstanbul / Türkiye, muhittinsagirli@istanbul.edu.tr, ORCID: 0000-0001-9558-3891
}

\section{$\ddot{\mathbf{O} z}$}

Genel olarak birinci sınıflarda eğitim-öğretime, özel olarak ise ilk okuma yazma öğretim sürecine birçok paydaşın olumlu, olumsuz etkisi söz konusudur. Bu sürecin paydaşları; eğitim-öğretim programı, okul ve çevre, öğretmen, öğrenci; özellik ve hazır bulunuşluk düzeyleri ve aile özelinde velidir. Tüm paydaşların sürece; az çok, olumlu olumsuz, ayrı ayrı veya ortak etkileri söz konusudur. Günümüzde eğitim-öğretim sürecinin önemli paydaşlarından olan ailenin, çocukların okul başarısındaki sorumluluğu, önemi, yeri dolayısı ile çocukların okul başarısındaki etkisi oldukça artmıştır. Artık çocukların okul dışında öğretmenleri olan anne-babaların, okul ve öğretmen ile etkili iletişim ve işbirliği içinde olması gereklilik ötesinde zorunluluktur. Bu sebeple, paydaşlardan birisi olan aile özelinde velinin ilk okuma yazma öğretimine etki ve katkısını belirlemeye yönelik bu araştırma özel öneme sahiptir. İlk okuma yazma öğretim sürecinin önemli paydaşlarından biri olan aile özelinde velinin, sürece çeşitli yönlerden etkisini öğretmen görüşlerine göre incelemek üzere yapılan araştırma, nitel araştırma yöntemi desenlerinden durum çalışması olarak gerçekleştirilmiştir. İlk okuma yazma öğretim sürecinin önemli paydaşlarından biri olan aile özelinde velinin, sürece etkisininin, öğretmen görüşlerine göre incelendiği bu çalışma nitel araştırma yöntemi desenlerinden durum çalışması olarak gerçekleştirilmiştir. Verilerin toplanmasında, araştırmacı tarafindan hazırlanan, 6 açı uçlu sorudan oluşan yarı yapılandırılmış görüşme formu kullanılmıştır. Araştırma, uygun ölçüt ve örnekleme yöntemi ile

* Sorumlu Yazar. Tel: +90 5326249918 | Araştırma Makalesi.

Makale Tarih Bilgisi. Gönderim: 01.04.2021, Kabûl: 18.05.2021, Erken Görünüm: 29.05.2021, Basım: Aralık, 2022.

(C) 2022. Kalem Eğitim ve Sağlık Hizmetleri Vakfı. Bütün Hakları Saklıdır. ISSN: 2146-5606, e-ISSN: 2687-6574. 
belirlenen ve araştırmaya katılmayı gönüllü olarak isteyen, 2020-2021 eğitim-öğretim yılında İstanbul ilinde devlet ilkokullarında görev yapan 12 sınıf öğretmeni ile görüşülerek gerçekleştirilmiştir. Verilerin çözümlenmesinde, nitel veri analizi tekniklerinden betimsel analiz kullanılmıştır. Araştırmada ulaşılan sonuçlardan bazıları şunlardır: Velinin, eğitim-öğretim düzeyinin yüksek olmasının öğrencinin, okul ve ilk okuma yazma öğretim sürecindeki başarısını olumlu yönde etkilediği belirlenmiştir. İlk okuma yazma öğretiminde uygulanan yöntem-teknik konusunda velinin etkisinin, konuya ilişkin bilgi, ilgi ve özelliklerine göre farklılaştığ 1 belirlenmiştir. Öğretim sürecine veli desteği kadar verilen desteğin doğru olmasının gerektiği belirlenmiştir. İlk okuma yazma öğretim sürecinde öğrencinin başarısına velinin etki ve tepkisinin genel olarak olumlu olduğu, başarısızlık durumuna ise olumsuz olduğu, öğrenci motivasyonunun da bundan etkilendiği belirlenmiştir.

Anahtar Kelimeler: İlk okuma yazma öğretimi; Yöntem; Birinci sınıf; Birinci sınıf öğretmeni; Aile; Veli.

\title{
Investigation of the Parents' Effect on the First Literacy Teaching Process According to Teachers' Opinions
}

\begin{abstract}
Many educational stakeholders have an impact on education in the firstgrades in general and on the first literacy teaching process in particular. The stakeholders of this process are the education program, the school and the environment, the teacher, the student, the characteristics and readiness levels, and the parents in the family. All these stakeholders, separately or together, have more or less, positive or negative effects on the process. Family is an important stakeholder today and its effects on children's school success have increased considerably. Parents who are the teachers outside the school must be in effective communication and cooperation with the school and the teacher. In this context, this research is of special importance to determine the parental impact on the first literacy teaching. The general purpose of the study is to determine the parental impact on the first literacy teaching process through the evaluations of teachers in line with the research conducted on this subject and to create suggestions for stakeholders. The research was carried out with qualitative research method and as a case study from qualitative research designs. A semi-structured interview form consisting of 6 open-ended questions prepared by the researcher were used for data collection. The research was conducted by interviewing 12 classroom teachers, who volunteered to participate in the study, working in public primary schools in Istanbul in the 2020-2021 academic year. Teachers were selected with the appropriate criteria and sampling method. From
\end{abstract}


the qualitative data analysis techniques, descriptive analysis was used in analyzing the data. Some of the results obtained in the study are as follows: It has been determined that the higher education and training of the parents have a positive effect on the success of the student at school and the first reading and writing teaching process. It has been determined that the effect of parents on the method-technique applied in the teaching of first reading and writing varies according to the knowledge, interests and characteristics of the subject. It was determined that the support given to the teaching process should be as correct as the parent support. In the first reading and writing teaching process, it was determined that the effect and reaction of parents on student success was generally positive, the failure status was negative and student motivation was also affected by this.

Keywords: First literacy teaching; Method; First-grade; First-grade teacher; Family; Parents.

\section{Extended Summary}

\section{Purpose}

The general purpose of the study is to determine the parental impact on the first literacy teaching process through the evaluations of teachers in line with the research conducted on this subject and to create suggestions for stakeholders. Within the scope of this general purpose, the study sought to answer the following questions:

1. How do parents' level of education affects the first literacy teaching process?

2. How does parental impact on the first literacy teaching

a. Differ according to the method applied in teaching?

b. Effect the student's success-failure status and motivation?

c. Differ according to the parents' communication with the teacher in the education process and their role as a mediator between the student and the teacher?

3. What is the parental impact on the first literacy teaching process in terms of managing the time the student spends at home?

4. What is the parental impact on the first literacy teaching process in terms of approach to and the supply of the resources and tools that the teacher finds necessary?

5. What is the parental impact on the first literacy teaching process in terms of ensuring the student's attendance to school in the first grade?

6. What is the parental impact on the first literacy teaching process in terms of student's performance in home activities? 


\section{Method}

The research was carried out with qualitative research method and as a case study from qualitative research designs. Case study is an empirical research type that works on a current phenomenon within its real-life framework (content), where the boundaries between the phenomenon and its content are not clear, and when there are more than one source of evidence or data. In other words, it is a research method that is based on questions of "how" and "why" which allows the researcher to examine a phenomenon or event that cannot be controlled in depth (Yıldırım and Şimşek, 2018). Non-probabilistic, convenience and criterion sampling methods were used in this study.

The basic criterion for determining the classroom teachers to participate in the study and including them in the study group was to have conducted education in the first grade at least three times before and to have performed first literacy teaching with sentence method at least once before 2005. The research was carried out by interviewing 12 classroom teachers who were determined with the appropriate criteria and sampling method, who worked in public primary schools in Istanbul in the 2020-2021 academic year and participated in the study voluntarily. In the study, a semi-structured interview form consisting of 6 open-ended questions developed by the researcher was used in order to get the opinions of classroom teachers about the parental impact on the first literacy teaching process. The research data were obtained from the semi-structured interview form created by the researcher and from the semi-structured interviews with 12 classroom teachers in the study group.

Descriptive analysis, one of the qualitative data analysis techniques, was used to analyze the data obtained as a result of the interviews. While conducting descriptive analysis, the data obtained are summarized and interpreted according to previously determined themes (Yıldırım and Şimşek, 2018). findings were supported by direct quotations from classroom teachers' views. Quotations from teachers' opinions were used without giving the real names of the teachers.

\section{Result and Discussion}

The results obtained from the study can be summarized as follows:

In line with the findings related to the impact of parents' level of education, on the first literacy teaching process; the high education level of the parent or even one of the family members positively affects the success of the child and the first literacy teaching process at this important stage. 
The parents' effect on the education process differs according to the parent's knowledge, interest and character in terms of the method and technique applied in the first literacy teaching process, and whether the parent is involved in the process has a positive or negative effect.

Parental support, and family support in general, is undoubtedly very important in teaching reading and writing. However, as important as parent and family support is the accuracy of the support provided.

Parents' interest varies according to the stages in the first literacy teaching process. The greatest interest is seen in the preparation process, which is the first stage of the adaptation and method. Parents instill negative perceptions about school, process and teacher in preschool children, give children wrong information that is against method and technique, and have different expectations about education, which causes a relative decrease in interest at other stages.

Parents' effect and reaction to the student's success or failure status and motivation in the first literacy teaching process is generally positive if the student is successful and negative if the student is unsuccessful. This situation affects the motivation of the student in the same way.

In the reading and writing process, teachers see the parent as an important actor of the process. The involvement of the parent in the teaching process with the help of the teacher ensures that the teaching is carried out in strong communication and cooperation and the process results in a positive way.

Parents controlling the quality of the time spent by the student outside of school, especially at home, providing a suitable studying environment at home, supervising the child in a positive way, dealing with his/her needs and happiness positively affect the child and therefore the first literacy teaching process.

In the first literacy teaching process, the use of qualified tools is important and it provides and increases the motivation and success of the teacher and student. Teachers find the basic resources provided by the Ministry of Education inadequate and unqualified. In general, parents have a positive attitude towards the teachers' request for equipment and auxiliary resources, trust the teacher and show effort to support the process. However, they do not 
take care of supply and quality. However, they do not pay enough attention to provide the required products and their quality.

The most important and even the first factor affecting the process in achieving success in the first literacy teaching process is ensuring that the student continues to his/her education; provision, control and responsibility of which lies within the parents.

Home activities are also the duties of the parents. The parents are expected to follow the homework of the student in a planned and regular manner, to give the student a sense of responsibility in this regard, and to create a suitable time and space for the student to perform the work in the home environment comfortably.

\section{Giriș}

Bilgi çağını yaşayan dünyamızda birey ve toplumun geleceği, bilgiye ulaşma, bilgiyi kullanma ve üretme becerilerine bağlıdır. Bu becerilerin kazanılması ve hayat boyu sürdürülmesi çağdaş bir eğitimi gerektirmektedir. $\mathrm{Bu}$ süreçte uygulanan eğitim yaklaşımları ve programları büyük önem taşımaktadir.

İlkokul birinci sınıf örgün eğitimin sisteminin, ilk okuma yazma öğretimi ise öğrenciye yönelik hazırlanan resmi eğitim sürecinin ilk ve en önemli basamağıdır. Eğitim sisteminde, tüm eğitim kademelerini etkileyen ilkokul dönemi farklı bir yere, işleve ve öneme sahiptir. İlkokul döneminin üzerinde durulması gereken en önemli kademesi ise aile ortamından muhtemelen ilk kez tamamen farklı bir çevreye geçişin başlangıcı olan, ilkokul birinci sınıf1dır. Birinci sınıf ile öğrenciler, hem sosyal bakımdan farklı bir ortama hem de bütün yaşantısını etkileyebilecek olan öğrenme sürecine girmektedir. Bu süreç ve sınıftaki öğrenme ve öğretme sürecinin temel uygulamalarının başında ilk okuma yazma çalışmaları gelmektedir. Birinci sınıf öğretmeninin yönetiminde yapılan öğrenme öğretme etkinlikleri ile öğrencilere sadece okuma yazma mekanizmasının nasıl işlediği kavratılmamakta, bu sınıf ve etkinliklerle tüm eğitim-öğretim kademelerinde sürdürülecek olan hayatının temelleri de atılmış olmaktadır. Bireyin sınav ve hayat başarısı için birinci sınıf ve ilk okuma-yazma öğretimi ciddi öneme sahiptir (Sağırlı, 2019). İlk okuma yazma çocukların hayatlarındaki ilk öğrenme deneyimleridir. Bireyin diğer öğrenmelerinin temelini oluşturma, okul ve sosyal hayatındaki başarısı ile sahip olduğu potansiyelini geliştirme bakımından son derece önemlidir. Ayrıca okuma 
yazma, bireyin iletişim becerisi (Boody, 2003), beyin süreçlerini kullanabilmesi (Güneş, 1997) ile dil ve bilişsel gelişiminde de önemli bir yere sahiptir (Şenel, 2004). Yapılan çalışmalara göre; ilk okuma yazma öğretiminde başarı, devam edecek olan eğitim-öğretim hayatının başarısının da belirleyicisidir (Ogano, 2012; Strickland ve Riley-Ayers, 2006).

Birinci sınıfta öğretmen yönetim ve denetiminde öğrencilere; özenle çalışma, düzenli, tertipli ve temiz olma, sorumluluk alma, çalışmaları zamanında, tam ve doğru yapma, araştırma, kendi kendine çalışma ve öğrenme, iletişim, zamanı etkili kullanma, kendini ve zamanı yönetebilme, doğru okuma, yazma vb. bilgi, beceri, alışkanlıklar kazandırılabilir. Bu kazanımlar aile desteği ile de pekiştirilir ise öğrenciler, hayat boyu bunları geliştirerek sürdürür.

Genel olarak birinci sınıflarda eğitim ve öğretime, özel olarak ise ilk okuma yazma öğretim sürecine birçok paydaşın olumlu, olumsuz etkisi söz konusudur. Bu sürecin paydaşlarını; eğitim ve öğretim programı, okul ve çevre, öğretmen, öğrenci; özellik ve hazır bulunuşluk düzeyleri ve aile özelinde veli şeklinde belirtebiliriz. Söz konusu tüm paydaşların, sürece değişik şekillerde ayrı ayrı veya ortak etkileri söz konusudur. Bu etkiler nitelikli ve olumlu yönde olursa öğretmen, verimli şekilde çalışır ve süreç başarı ile yürütülüp sonuçlanır. Ancak yine paydaşlardan kaynaklanan çeşitli sebepler ile tersi durumda süreç, verimsizlik ve başarısızlık ile sonuçlanabilir (Sağırlı, 2019). Çocuğun okula başlaması ile onun okul başarısı üzerinde etkili olan; okul, öğretmen, program vb. paydaşlar da sürece dâhil olacaktır. Sürecin başlaması ile ailenin önem ve sorumluluğu ortadan kalkmayacaktır. Etmenler, çevresel faktörler ile toplumun daha geniş kesimini kapsayarak genişleyecektir. Bu süreçte yine, çocuk üzerinde etki alanı çok geniş olan aile ve aile özellikleri, öğrencinin okul başarısındaki en önemli çevre faktörünü oluşturmaktadır (Çelenk, 2003).

Çocuğun aile içinde oluşan ilk öğrenme deneyimleri ile okulda öğretmen ile kazanılanların ailece desteklenmesi, onların okuldaki öğrenme girişimlerine destek sağlayarak öğretmenin sınıf içi etkinliklerdeki başarı düzeyini yükseltecektir. Bu nedenle öğretmenlerin, çocuğun ev ortamlarını iyi değerlendirmeleri onun daha etkili ve nitelikli eğitimine imkânlar oluşturmaları için aile ile iletişim kurmaları ve işbirliğine gitmeleri gerekli ve önemlidir. Burns, Roe ve Ross (1992)'a göre, çocuğun evdeki öğrenme deneyimleri, okulda öğrenme çabasına destek oluşturmakta ve sınıf içi etkinliklerde 
başarısını arttırmaktadır. Bundan dolayı öğretmenlerin, çocuğun aile ortamlarını iyi değerlendirmeleri ve aile ile iletişim içinde olmaları önemlidir. Annebaba ve öğretmenler, çocuklara elverişli bir öğrenme ortamı oluşturmak için de ortak çaba göstermelidir.

İlk okuma yazma öğretimi, çocukların okula yeni başladığı ve bu sebeple çeşitli kaygılar taşıdığı kritik dönemde başlayan süreçtir. Bu dönem öğretmenlerine, önemli görevler ve sorumluluklar düşmekle birlikte çocuklar için aile desteği oldukça önemlidir. Henüz tam olarak bağımsız çalışma alışkanlığının kazanılmadığı ve sorumluluklarının tam olarak bilincinde olunmadığı bu dönemde ailelerin desteği öğrenci başarısında belirleyici olmaktadır. Çocuklar vakitlerinin büyük kısmını ailesiyle geçirdiği için, ebeveynlerin çocukların eğitiminde kilit bir rolü bulunmaktadır (Isaacs, 2012).

Günümüzde eğitim ve öğretim sürecinin önemli paydaşlarından olan ailenin, çocukların okul başarısındaki sorumluluğu, önemi, yeri dolayısı ile çocukların okul başarısındaki etkileri oldukça artmıştır. Artık çocukların okul dışında öğretmenleri olan anne-babaların, okul ve öğretmen ile etkili iletişim ve iş birliği içinde olması gereklilik ötesinde artık zorunluluktur. Bu sebeple, paydaşlardan birisi olan aile özelinde velinin ilk okuma yazma öğretimine etki ve katkısını belirlemeye yönelik bu araştırma özel öneme sahiptir. Alanyazın incelendiğinde, çalışmaların bazı bölümlerinde, velinin ilk okuma yazma sürecine etkisine değinilmiştir (Adıgüzel ve Karacabey, 2010; Akın, 2016; Babayiğit ve Erkuş, 2017; Başar, Göncü ve Baran, 2021; Başar ve Tanış-Gürbüz, 2020; Bayat, 2014; Bektaş, 2013; Demir ve Ersöz, 2016; Erbasan ve Erbasan, 2020; Yiğit, 2009). Ancak doğrudan veli etkisinin incelendiği çalışmaya rastlanılmamıştır. Bu anlamda çalışmanın, alanda önemli bir boşluğu dolduracağ 1 düşünülmüşsür.

Araştırmanın genel amacı, ilk okuma yazma öğretim sürecinin önemli paydaşlarından biri olan aile özelinde velinin, sürece çeşitli yönlerden etkisini, öğretmen görüşlerine göre incelemektir. Bu amaçla araştırmada şu sorulara cevap aranmıştır:

1. Velinin eğitim-öğretim düzeyi, ilk okuma yazma öğretimi ve sürecini nasil etkilemektedir?

2. Velinin, ilk okuma yazma öğretim sürecine etkisi;

a. Öğretimde uygulanan yönteme göre nasıldır?

b. Öğrencinin, başarı-başarısızlık durumu ve motivasyonuna etki bakımından nasıl değerlendirilir? 
c. Öğretmen ile öğrenme öğretme sürecindeki iletişim, etkileşimine ve öğrenci-öğretmen arasındaki arabulucu rolü üstlenmesine göre nasildir?

3. Velinin, öğrencinin okul dışında evde geçirdiği süreci yönetme bak1mindan nasıl sonuçlar doğurur?

4. Velinin, ilk okuma yazma öğretimi için gerekli araç-gereçler ile öğretmenin, öğretim için kaynak talebine yaklaşım ve temini yönünden nasildir?

5. Öğrencinin, birinci sınıfta okula devamını sağlama bakımından nası1dir?

6. Öğrencinin ev etkinliklerindeki performansı yönünden nasıldır?

\section{Yöntem}

\section{Araştırmanın Modeli}

Betimsel tarama modeline göre tasarlanan bu çalışma, nitel araştırma desenlerinden durum çalışması olarak gerçekleştirilmiştir. Durum çalışması, güncel bir olguyu kendi gerçek hayat çerçevesi (içeriği) içinde çalışan, olgu ve içinde bulunduğu içerik arasındaki sınırların kesin hatlarıyla belirgin olmadığı ve birden fazla kanıt veya veri kaynağının mevcut olduğu durumlarda kullanılan görgül bir araştırma diğer bir tanımla, nasıl ve niçin sorularını temel alan, araştırmacının kontrol edemediği bir olgu ya da olayı derinliğine incelemesine imkân veren araştırma yöntemidir (Yıldırım ve Şimşek, 2018).

\section{Çalışma Grubu}

$\mathrm{Bu}$ araştırmada amaçl1, uygun ve ölçüt örnekleme yöntemleri kullanılmıştır. Amaçlı örnekleme, zengin bilgiye sahip olduğu düşünülen durumların derinlemesine çalışılmasına imkân sağlar. Ölçüt örnekleme ise bir durumu, araştırmacının derinlemesine inceleyebilmesi için örnek olay türleri belirlemek istediğinde kullanılır. Bu örnekleme yöntemleri, araştırmaya hız ve pratiklik kazandırır (Büyüköztürk, Kılıç-Çakmak, Akgün, Karadeniz ve Demirel, 2012; Neuman, 2007; Yıldırım ve Şimşek, 2011). Araştırmaya katılacak sınıf öğretmenlerinin belirlenip çalışma grubuna dâhil edilmesinde, daha önce en az üç defa birinci sınıflarda eğitim ve öğretimi yürütmüş ve yine 2005 yılı öncesinde en az bir defa cümle yöntemi ile ilk okuma yazma öğretimini gerçekleştirmiş olma temel ölçüt olarak belirlenmiştir. 2005 yılı ve öğretim programı öncesi ilk okuma yazma öğretiminde cümle yöntemi ile öğretim gerçekleştirildiğinden katılımcıların, en az bir defa cümle yöntemi ile öğretimi yürütmüş olmaları ölçütü de getirilmiştir. Bu ölçüt ise, 2. (a) araştırma sorusu 
için gerekliliktir. Araştırma, uygun ölçüt ve örnekleme yöntemi ile belirlenen ve araştırmaya katılmayı gönüllü olarak isteyen, 2020-2021 eğitim ve öğretim yılında İstanbul ilinde devlet ilkokullarında görev yapan 12 sınıf öğretmeni ile görüşülerek gerçekleştirilmiştir. Katılımcılara ilişkin demografik ve mesleki bilgiler tabloda belirtilmiştir.

Tablo 1. Araştırmaya Katılan Öğretmenlerin Demografik ve Meslekî Bilgileri

\begin{tabular}{|c|c|c|c|c|c|c|c|}
\hline Çalışma Grubu & 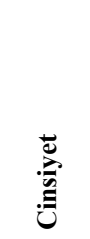 & $\stackrel{\pi}{\tilde{\lambda}}$ & 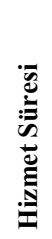 & 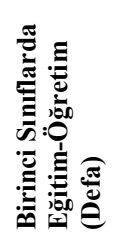 & 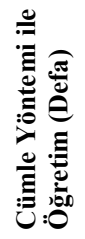 & 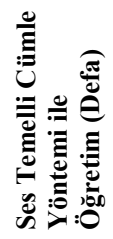 & 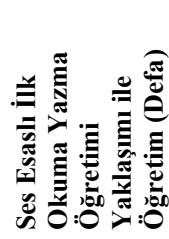 \\
\hline Öğretmen 1 (Ö 1) & Erkek & 45 & 21 & 4 & 1 & 2 & 1 \\
\hline Öğretmen 2 (Ö 2) & Erkek & 43 & 20 & 5 & 1 & 3 & 1 \\
\hline Öğretmen 3 (Ö 3) & Erkek & 40 & 19 & 4 & 2 & 1 & 2 \\
\hline Öğretmen 4 (Ö 4) & Erkek & 45 & 22 & 6 & 3 & 3 & - \\
\hline Öğretmen 5 (Ö 5) & Kadın & 44 & 21 & 5 & 2 & 2 & 1 \\
\hline Öğretmen 6 (Ö 6) & Erkek & 56 & 24 & 7 & 4 & 2 & 1 \\
\hline Öğretmen 7 (Ö 7) & Erkek & 50 & 28 & 13 & 10 & 3 & - \\
\hline Öğretmen 8 (Ö 8) & Kadin & 59 & 38 & 9 & 4 & 3 & 2 \\
\hline Öğretmen 9 (Ö 9) & Erkek & 52 & 26 & 7 & 3 & 3 & 1 \\
\hline Öğretmen 10 (Ö 10) & Kadın & 56 & 25 & 6 & 2 & 3 & 1 \\
\hline Öğretmen 11 (Ö 11) & Kadın & 52 & 31 & 7 & 3 & 2 & 2 \\
\hline Öğretmen 12 (Ö 12) & Kadın & 38 & 18 & 5 & 1 & 3 & 1 \\
\hline
\end{tabular}

Tablo 1'de çalışma grubunda yer alan öğretmenlerin; 5'i kadın, 7'si erkek, en düşük yaş 38 , en yüksek 59 , yaş ortalamaları 48.5 , hizmet süresi en az olan 18, en yüksek olan 38 yıl, ortalama hizmet süreleri 24.5 yıl, çalışmaya katılan öğretmenlerin en az 4, en çok 13 defa birinci sınıflarda eğitim-öğretimi yürüttükleri görülür. Katılımcı öğretmenlerin hemen hepsi, üç farklı yöntem/yaklaşım ile öğretimi gerçekleştirmiştir.

\section{Veri Toplama Aracı}

Araştırmada, sınıf öğretmenlerinin ilk okuma yazma öğretimine veli etkisine ilişkin görüşlerini almak amacı ile 6 açık uçlu sorudan oluşan yarı yapılandırılmış görüşme formu araştırmacı tarafından geliştirilmiştir. Form kapsam geçerliliği için Temel Eğitim Bölümü'nde görev yapan nitel yöntem konusunda uzman 2 öğretim üyesi tarafından incelenmiş ve gerekli öneriler alındıktan sonra soru sayısı değişmeden pilot uygulamaya geçilmiştir. Taslak görüşme formu, çalışma grubunda yer alan öğretmenlerle aynı özellikte farklı 3 
öğretmene uygulanmıştır. Pilot uygulama ile soruların anlaşı1ma durumları ve niteliği kontrol edilmiş ve forma son hali verilmiştir.

\section{Verilerin Toplanması}

Araştırma gerekli "Etik Kurul” izni alınarak yapılmıştır (2021/54 Sayılı Etik Kurul Onayı Say1: E-74555795-050.01.04-48994).

Araştırma verileri, çalışma grubunda yer alan 12 sınıf öğretmeninden yarı yapılandırılmış görüşme tekniği ile elde edilmiştir. Yarı yapılandırılmış görüşme tekniği, önceden belirlenmiş amaç için soru sorma ve cevap alma yoluna dayalı karşılıklı iletişim sürecidir. Yarı yapılandırılmış görüşmede araştırmacı, görüşme yaptığı kişinin verdiği bilgilere odaklanarak görüşme yapılan kişinin araştırma konusu hakkındaki görüşlerini derinlemesine öğrenir. Yarı yapılandırılmış görüşme tekniği, önceden hazırlanmış görüşme formuna bağlı olarak yapıldığı için kolaylık sağlamaktadır (Güler, Halıcıoğlu ve Taşğın, 2015; Yıldırım ve Şimşek, 2018). Araştırmacı tarafından öğretmenlere kişisel bilgilerinin gizli tutulacağı bildirilmiştir. Öğretmenlerle yapılan görüşmelerde en kısa süren görüşme 40 dakika, en uzun süren görüşme ise 55 dakika, ortalama görüşme süresi ise 47 dakikadır.

\section{Verilerin Analizi}

Görüşmeler sonucunda elde edilen verilerin çözümlenmesinde nitel veri analizi tekniklerinden betimsel analiz kullanılmıştır. İç güvenirliği sağlamada kullanılan stratejilerden biri, toplanan verilerin öncelikle betimsel bir yaklaşımla doğrudan sunulmasına ilişkindir (Yıldırım ve Şimşek, 2018). Bu bağlamda araştırma ile elde edilen bulgular, araştırmada yer alan veri birimlerinden yapılan doğrudan alıntılar ile desteklenmiştir. Alıntılarda katılımcıların gerçek isimleri değil, araştırmacı tarafından öğretmen 1 (Ö1), öğretmen 2 (Ö2) ... şeklinde verilen kod isimler kullanılmıştır. Öğretmen görüşlerinden yapılan alıntılar tırnak işareti içinde sunulmuş ve sonunda parantez içinde kodu ile belirtilmiştir.

\section{Bulgular}

$\mathrm{Bu}$ bölümde, öğretmenlerin araştırma sorularına verdikleri cevaplardan elde edilen bulgulara yer verilmiştir.

\section{Velinin Eğitim-Öğretim Düzeyinin İlk Okuma Yazma Öğretimi ve Sü- rece Etkileri}

Araştırmanın birinci alt problemi, velinin eğitim ve öğretim düzeyinin ilk okuma yazma öğretimi ve sürece etkisini belirlemeye yöneliktir. İlgili 
soruya verilen cevaplardan elde edilen bulgulara göre velilerin, eğitim ve öğretim düzeylerinin yüksek olmasının ilk okuma yazma öğretim sürecini olumlu etkilediği yönündedir (f:8). Öğrenim düzeyi yüksek olan ve olmayan veliler için öğretmenlerden bazıları şunları ifade etmiştir:

"Olumlu etkilemektedir. Velinin eğitim düzeyi arttıkça, eğitim öğretime bakışı olumlu olunca, beklentiler yüksek olunca, süreç olumlu etkileniyor." (Ö7)

"Eğitim düzeyi yüksek veliler okuma yazma döneminde ve diğer aşamalarda hem bizlere hem de öğrenciye olumlu katk sağlamakta ve okuma yazma dönemini zorlanmadan geçilmesini sağlamaktadır." (Ö12)

"Eğitim öğretim düzeyi yüksek veli grubu eğitimin önemini kavradiğg için daha fazla önemsiyor ve daha çok destek veriyor. Bu sebeple veli potansiyeli de en az çocukların zekâ, hazır bulunuşluk ve çevre faktörü kadar başartyl etkileyen ve artttran bir unsurdur." (Ö11)

"Velinin eğitim-öğretim düzeyinden ziyade eğitim öğretime duyduğu saygl, eğitime değer verme, okuma yazma sürecini olumlu etkilemektedir. Velinin akademik düzeyinin gelişmişs olması da sürecin daha bilinçli ilerlemesine katkı sağllyor." (Ö3)

"Velinin eğitim-öğretim düzeyi arttıkça, ilk okuma yazma sürecinin de o oranda olumlu etkileneceği yaygın inanışına rağmen, bunun tersi durumları da tecrübe ettim. Illk görev yaptığım okul, sosyo-ekonomik olarak dezavantajlı bir bölgede olmasina, velilerimin pek çoğunun okuma yazma bilmemesine rağmen, akademik anlamda olmasa bile çocuklarını motive etmekte, okuldan gelen yönergeleri uygulama anlamında destekleyici tutumlar sergiliyorlardı. O okulda görev yaptı̆̆ım süre boyunca, çocuklariyla birlikte okuma yazma ögrenen, bu konuda okuldan destek isteyen pek çok velim oldu. Bunun yanı sıra, ebeveynin eğitimögretim düzeyi lisans/lisansüstü olup da çocuğuna gerçek anlamda destek olmayan/olamayan ebeveynler de tanıdım." (Ö10)

"Eğitim düzeyi vb. dişında velinin eğitime baklşı önemli, çocuğu vasat olsa da çabalayabiliyor, eğitimin burada önemi kalmıyor." (Ö8)

Velilerin eğitim ve öğretim düzeyi yüksek olmasa da okulun önemini bilip gerekliliğine inanmalarının, bunu ihtiyaç olarak görmelerinin de yine ilk okuma yazma öğretim sürecini olumlu etkilediği yönündedir $(f: 4)$.

\section{Velinin, Öğretimde Uygulanan Yöntem, Öğrencinin Başarı Durumu ve Motivasyonu vb. Yönlerinden İlk Okuma Yazma Öğretim Sürecine Et- kisi}

$\mathrm{Bu}$ probleme ilişkin bulgular, içinde yer alan unsurlar doğrultusunda alt problem şeklinde maddeler halinde belirtilmiştir. 


\section{Öğretimde Uygulanan Yönteme Göre İlk Okuma Yazma Öğretim Sürecine Etkisi}

Velinin, öğretimde uygulanan yönteme göre ilk okuma yazma öğretim sürecine etkisine ilişkin bulgulara göre; velinin, bilgi, ilgi ve özellikleri, yönteme ilişkin ilk okuma yazma öğretim sürecine olumlu veya olumsuz yönde müdahil olmasını ve etkisini belirlemektedir (f:6). Bu doğrultuda birkaç öğretmen görüşü şu şekildedir:

"Anlayabileceği bir yöntem ise kendini daha hâkim hissederek katılım sağllyor. Anlamayacağ yöntemler ise uzak durup çocuktaki değişimleri gözlemliyor. Eksikleri bularak öğretmeni, okulu, çocuğunu suçlamayı tercih ediyor. Kendisi hiç karışmadı̆g için hatalı bulmuyor, sorunun dışarıda olduğunu düşünüyor." (Ö1)

"Veli uygulanan yöntem hakkinda bilinçliyse olumlu katkı sağlamakta, bilinçli değilse okuma yazma öğretimi keşmekeş bir hal almakta, okulda verilen bilgi ile evde verilen yanlışlarla çocuğun kafası karışmaktadır. Bunu, harflerin yazllış yönlerinde ve sesleri verme aşamasında çok yaşamaktayız. Özellikle yazma döneminde bunu düzeltmesi çok zor oluyor. Çocuk evde nasll ögrendiyse öyle yazma devam ediyor." (Ö6)

"Illk okuma yazma ögretiminde cümle yönteminin daha kolay uyum sağlanan yöntem olduğunu ifade edebilirim. Ses temelli cümle yöntemi ses ve hece aşamasinda eğitim düzeyi ilkokul ve okuma bilmeyen velilerde yanlls yönlendirmeler yüzünden problemler oluşturmaktadır. Zamanla velilerdeki eğitim düzeyi iyileştiğinden ilerde ses temelli cümle yöntemi daha kolay uygulanacak sistem olabilir. Ses esasl okuma yazma yaklaşımı ise harf karakterleri bakımından ses temelli cümle yöntemine göre daha kolaydır." (Ö9)

"Özellikle ses temelli cümle yöntemine ilk geçtiğimiz zamanlarda ( $k i$ aynı zamanda bitişik eğik yazıya da geçilmişsi) veliye ayrıca sistemin özellikleri ile ilgili sikça bilgi vermek gerekmişti. Örneğin sessiz harflerin verilişinde velilerin be, ce, çe... şeklinde ögrretmeleri, harflerin çizim yönlerini yanlış göstermeleri olumsuz etkilerden biriydi." (Ö10)

"Ses esasl ilk okuma yazma öğretim sürecinde; velilerin çocuklara harflerin adinı söylemeleri süreci geriletmekte ve olumsuz etkilemekte. Özellikle bazı öğrencilerde okuma yazmaya geçişi zorlaştırmakta ve geciktirmekte. Sessiz harflerin adı söylendiğinde heceyi zihinde oluşturmak çocuk açısından zorlaşlyor. Bu özellikle 5. ve 6. seste oluşan heceler çoğaldlkça çocuklar zorlandığında veli paniğe kapılıp çocuklar üzerinde aşırı baskı oluşturuyor ve çocuğun kaygı düzeyini yükseltiyor. Bu da ögrenmeye ket vurabiliyor." (Ö11)

Bazı bulgulara göre ise; ilk okuma yazma öğretiminde uygulanan yöntemin tarihi ile velinin ilk okuma yazma öğrendiği yöntem ilişkisi, etkiyi 
belirlemekte (f:1). "Ses temelli ses esaslı okuma yazma yöntemi uygulanma tarihine bakıldığında günümüz anne babaların bilgi sahibi olduğu bir yöntem değil." (Ö3), bazısına göre ise, ilk okuma yazma öğretimine veli etkisi yönteme göre farkl1l1k göstermemektedir (f:1). "Veli etkisi okuma yazma sürecinde uygulanan yönteme göre değişmiyor. Yöntem umurunda bile değil." (Ö7).

\title{
Öğrencinin, Başarı-Başarısızlık Durumu ve Motivasyonuna Etki Bakımından İlk Okuma Yazma Öğretim Sürecine Etkisi
}

Öğrencinin, başarı-başarısızlık durumu ve motivasyonuna etki bakımından velinin, ilk okuma yazma öğretim sürecine etkisine ilişkin bulgulara göre, süreçte veli etkisi ve tepkisi, öğrenci başarısına göre olumlu, başarısızlığına göre olumsuz izlenmekte, velisi bulunduğu öğrencinin motivasyonu da aynı şekilde bundan etkilenmektedir (f:9). Konuya ilişkin öğretmen görüşleri şöyledir:

\begin{abstract}
"Genellikle veliler, çocuğunun başarısız olabileceğini, eksiklerini, destekte yetersiz kaldı̆̆ın düşünmüyor, görmüyor ve kabul etmiyor. Süreçte olumsuz giden, başarısızlık yönlü bir şeyler duyduğunda genellikle diğer çocuklar ile klyaslamaya başliyor, çocuğa oldukça sert tepki gösteriyor ve motivasyonunu tamamen bozuyor. Veli de çocuğu gibi başarı duymak, olumlu olarak eleştirilmek takdir edilmek istiyor. Olumsuz eleştirilerden hiç hoşlanmıyor, küsme hali çok slk rastladığımız bir durumdur." (Ö12)

"Çocuk, süreçte yavaş ve geriden geliyorsa aile çok panik olup çocuğu üzebiliyor.” (Ö5)

"Ailenin çocuk üzerindeki motivasyonu, verimli ders çalı̧̧ma ve akademik başarısını olumlu yönde etkilemektedir. Yalnız, veli çocuğunun kapasitesini bilip, o kapasitesini fazla zorlamaması lazım. Çocuğu kendisi ile yarış̧ırı yapabildiğinin en iyisini yapabilme yönünde motive etmesi gerekir." (Ö6)

"Başarılı olanlara güzel davranıldığını, övüldüğ̈̈nü, ödüllendirildiğini gördüm. Böyle çocuk daha istekli ve motive oluyor. Başarlsız olanlara kötü davranıldı̆̆ını, kırıcı sözler söylendiğini, ceza verildiğini gördüm. Böyle çocukların içine kapandı̆̆ını, okula gelme sevincini yitirdiğini, okuldan kaçma ĕgilimine girdiğini gördüm.” (Ö7)
\end{abstract}

\section{Öğretmen ile Öğrenme Öğretme Sürecindeki İletişim-Etkileşim ve} Öğrenci-Öğretmen Arasındaki Arabulucu Rolü Üstlenmesi Bakımından İlk Okuma Yazma Öğretim Sürecine Etkisi

Velinin, öğretmen ile eğitim-öğretim sürecindeki iletişim-etkileşim ve öğrenci-öğretmen arasındaki arabulucu rolü üstlenmesi bakımından, ilk 
okuma yazma öğretim sürecine etkisine ilişkin bulgulara göre, öğretim sürecinde veli, öğretimin önemli bir aktörü olarak görülüp öğretmen tarafından sürece dâhil edilmeli ve öğretim, veli ile güçlü iletişim ve iş birliği içinde yürütülmelidir. Bunun, sürece yine oldukça olumlu ve doğrudan katkısı olacaktır (f:8). Bu yönlü birkaç öğretmen görüşü şu şekildedir:

"Illk okuma yazma döneminde velinin ögrrenci ile ögretmen arasında köprü olması birinci slnı öğretmeninin olmazsa olmazıdır. Bu köprü sayesinde işlerimiz çok rahat ve kolay bir şekilde hallolmaktadır. Günümüzde artık iletişim araçları sayesinde velilerimiz ile iletişim kurmak çok kolay. Günümüzde, kurduğumuz Whatsapp grupları sayesinde sikıntılarımız hemen çözülüyor ve velinin de sorumlulukları artmış oluyor. Çünkü herşeyden haberleri oluyor. Nasil insan bilmediğinden görmediğinden sorumlu değildir ya... Düşü̈nsenize mesleğimin ilk ylllarında sürekli derdim veli toplantss yapmak ve velinin katılımını sağlamaktt." (Ö1)

"Veli ile öğretmen bir sorun yaşarsa bu süreç çocuğa kesinlikle olumsuz yanslyor. Ikkinci dönem sinıfima idare karart ile gelen (ögretmeni ile velinin sorun yaşaması sonucu) bir ögrencim ilk zamanlar dakikada on beş kelime okurken; bir iki ay içinde 80-90 kelimelere kadar çıkmiştl." (Ö4)

"Öğretmenin sürece hâkim olmasl, emin adımlarla süreci planlayarak ilerlemesi ve her aşamada sürece veliyi dâhil etmesi çok önemli. Ayrıca, ögretmen 1. grup seslerin sonunda heceler çoğaldığında veli ve çocuktaki kaygıyı ve paniği öngörüp öncesinde gerekli açıklamaları yapıp öncelikle veliyi rahatlatıp çocuğun üzerindeki stres ve baskiyı azalttığinda süreç çok kolay ve başarılı işliyor." (Ö11)

"Aile ne kadar çok ögretmenle iletiş̧im ve iş birliği içinde olur ise başarı o kadar çabuk geliyor ve nitelikli oluyor. Çocuğun özelliğine ve gelişimine göre özel ödev veriyorum. Çocuk geri kaldiysa ona göre çalışma yapıyorum." (Ö5)

"Veli öğretmen iletişimi iyi ise bu durum çocuğun başarısını olumlu yönde etkilemekte çocuğun ögretmenine sevgi ve saygisı oluyor, ögrretmen baktı̆̆ zaman gözlerinin içi gülü̈yor. Ë̆er ögretmen veli ilişskisi olumlu değilse, çocuğunun başarısızlı̆̆ının sebeplerini öğretmene mal eden velilerde, özellikle de ögretmen ile ilgili olumsuz düşüncelerini çocuğun yanında sesli dile getirdiyse bu da olumsuz yansimakta ögretmenine karşı olumsuz duygular beslemekte saygl ve sevgisi olmamakta bu da eğitimi olumsuz yönde etkilemektedir." (Ö6)

"Bazen okuma yazma sürecinde, süreci sekteye uğratan sorunlar oluyor. Bunu ögretmen de ögrenci de veli de fark etmiyor. Ya da biliyorlar ama ses çıkarmıyorlar. Böyle zamanlarda dı̧̧arıdan bir göz olaya müdahale etmeli, çözüm için harekete geçmelidir. Örneğin, her akşam 3, 
4 sayfa önlü arkalı fotokopi ödev veren arkadaşlar var. Ödevi ertesi güne de istiyorlar. Bütün veliler şikayetçi ama kimse bir şey yapmıyor veya yapamıyor. Öğrencinin konuya yaklaşımı; böyle bir sorunum giderilseydi mutlu olurdum, derslerime daha çok çalışırdım ve okula daha istekli gelirdim şeklinde. İste bir velinin konuyu seslendirmesi, iletişimle dile getirmesi bütün bunları sağlayacaktır." (Ö7).

\section{Velinin, Öğrencinin Okul Dışında Evde Geçirdiği Zamanı Yönetme Ba- kımından İlk Okuma Yazma Öğretim Sürecine Etkisi}

Öğrencinin, okul dişında evde geçirdiği zaman yönetimi bakımından velinin ilk okuma yazma öğretim sürecine etkisi alt problemine öğretmenlerin verdiği cevaplar ile ulaşılan bulgular, evde hazırlanan çalışma ortamı ve velinin çocuk üzerinde olumlu etkisi olacak denetimi, çocuğun okul dişında kaliteli vakit geçirmesi, ihtiyaçları ile ilgilenilmesi, mutlu olması tabi ki çocuğu ve ilk okuma yazma öğretim sürecini pozitif etkileyeceği yönlüdür (f:12). Konuya ilişkin birkaç örnek öğretmen görüşü şöyledir:

"Işsin gerçeği ilk okuma yazma sürecinde de daha ileriki aşamalarda da bazen veliden akademik anlamda fazla destek beklediğimizi düşünüyorum. Bana göre velinin süreçte yapmast gereken öncelikle çocuğun fiziksel, duygusal, sosyal ihtiyaçlarını karşılaması. Yani, evde saatlerce oturup yazl yazdırmaları veya soru çözdürmeleri değil. Okul dışı zamanlarda çocuğun açık havada, doğada zaman geçirmesini, kendisine kitaplar okunup masal anlatılmasını, evde küçük sorumluluklar verilmesini, ilgisini çeken konularda araştırma yapması için alan açılmasını tercih ederim. Bu anlamda desteklenen çocuklar daha mutlu, özgüvenli, dolayısıyla ögrenmeye hazır oluyorlar. Özellikle ilk okuma yazma sürecinde verilen sayfalarca yazı ödevleri, evde çatışmaya, bezginliğe neden oluyor." (Ö10)

"Zaman yönetimi tabii ki çok önemli. Zamanı verimli kullanan ögrenciler kesinlikle daha başarll oluyor. Bunu da ailelerinden ögreniyor ve bu konuda doğru alışkanlıklar kazanıyorlar. Bu konuda aile, doğru rol model oluşturursa çocuklar da zamanı etkin ve verimli kullanma alışkanlı̆̆l gelişiyor." (Ö11)

"Veli, okul dışındaki süreci çocuğun isteği doğrultusunda, enerjisini atabileceği özgüvenini kazanabileceği (zekâ oyunlarl, kodlama, satranç, yüzme vb spor kulüpleri...) aktivitelerin de içinde olduğu program yapıp uygulayan velilerin çocuklarından ĕgitim ögretim ve diğer konularda olumlu dönüt alabiliyoruz. Bizim bölgemizde bu tür velilerin sayısı yok denecek kadar az diyebilirim." (Ö6)

“Velinin her düşündüğünün her yaptığının çocuk üzerinde etkisi vardır. Veli bu konuda bilinçli olmall süreci doğru yürütmelidir. Fakat ben, ögretmen olarak çocuğun okul dışı ortamını düzenleyebilen bir veli ile çalışmadım maalesef. Genelde çocuğun tüm sosyal ortamı okul ile 
sınırlandırılmıştı. Çocuklar tüm gün okulda okul çıkışı parkta, akşam olunca evde yemek sonrası hadi ödevini yap komutların alan ama yapamadan uyuyan ya da zorla yaptırllarak bıkkınlık yaratılan, bask kurulmuş çocuklar bunlar. Dolayısıla, ertesi gün baskının sebebini öğretmeni olarak gören, onunla bă̆ kurmayı reddeden, kendini iletişime kapatmış ya içine kapanık ya da agresif davranışları olan öğrenciler olarak ortaya çıkıyor." (Ö1)

Bu sonuçlar aslında ilk kısımdaki bulgunun, istenen, beklenen ve ideal olanlar olduğunu, ilk okuma yazma öğretimine etkilerinin de oldukça önemli olduğunu göstermekle birlikte uygulamada durumun büyük oranda böyle olmadığını ve tablo ile örtüşmediğini göstermektedir.

\section{Velinin, İlk Okuma Yazma Öğretimi İçin Gerekli Araç-Gereçler ile Öğ- retmenin, Öğretim İçin Kaynak Talebine Yaklaşım ve Temini Yönünden İlk Okuma Yazma Öğretim Sürecine Etkisi}

Velinin, ilk okuma yazma öğretimi için gerekli araç-gereçler ile öğretmenin, öğretim için kaynak talebine yaklaşım ve temini yönünden ilk okuma yazma sürecine etkisi alt sorusuna ilişkin öğretmenlerin ifadelerinden şu bulgular elde edilmiştir: Öğretmenlerin önemli kısmı, ilk okuma yazma öğretiminde nitelikli araç-gerecin; başarıyı, öğretmen ve öğrencinin motivasyonunu sağlayan ve artıran, önemli bir unsur olduğunu belirtmiştir. Milli Eğitim Bakanlığg'nın öğretim için temin ettiği ve öğretimde kullanılan temel kaynakları yetersiz ve niteliksiz bulmaktadır $(f: 4)$. Bu konuyu öğretmenler şöyle ifade etmektedir:

"Maalesef bakanlığın okuma yazma kitaplarının hazırlanıllışında özenli davranılmadığını düşünüyorum. Özel yayınevlerinin kaynakların düşününce çok vasat. (şarkıll, animasyonlu, bol örnekli, renkli...) Araçgereç ve kaynak talebinde ipin ucunu kaçıran arkadaşlarımız oluyor. Genelde veli uygun, mantikll isteklere itiraz etmiyor ve olumlu yaklaşlyor. Çalışmalarda seçeneklerin fazla olmasl, şarkalar, resimli kitaplar, animasyonlar, ses sezdirmeleri ... okuma yazmayı eğlenceli hâle getiriyor." (Ö7)

"Ne yazık ki; sadece MEB 'in verdiği kitaplarla bu süreci etkin bir şekilde gerçekleştirmek çok mümkün değil. Kitaplar çok yeterli değil. Bu sebeple ek kaynak kullanmak zaruri bir hal ald uzun bir zamandır. Tabii ki ek kaynakların ve materyallerin alınması aşamasında velinin süreci ve ögretmeni desteklemesi kesinlikle olumlu katkr sağlamakta. Ders materyalleri ögrenmeyi desteklediği için hem dersi daha zevkli hale getirmekte hem de ögretmen ve çocuk açısından süreci kolay ve başarılı kllmakta." (Ö11) 
Veli, öğretmenin araç-gereç ve yardımcı diğer kaynakları talep etmesinin, çocuğu ve öğretimi için gerekliliğini, öğretime mutlaka katk1 sağlayacağını bilmekte ve öğretmene güvenmektedir. İlk okuma ve yazma öğretiminde öğretmenin gerekli gördüğü temel araç-gereçler ve süreçte lüzumu halinde yardımcı kaynak ve araç-gereç talebine veliler genel olarak olumlu bakmakta ve sürece destek olma gayreti göstermekte ancak, teminde ve nitelikte özen göstermemektedirler (f:6). Konuya ilişkin birkaç öğretmenin görüşü şöyledir:

"Genelde eğitim ve ögretimin ilk aşaması olduğu için veliler, çocukların araç gereçlerini sağlamaya özen gösteriyorlar. İlk okuma yazma ögretim sürecinde bu hususta olumsuzluk yaşamıyoruz. Ancak veli, ders araç-gereçlerini alırken çocuğun tercihine birakttğ için çocukta (kalem, kalemtıraş, kalem kutusu, silgi...) tercihini oyuncak türü araç gereçler seçtiği için (araba şeklinde kalemtıraş, bebek şeklinde silgi...) okuma yazma ögretim safhasında etkinliklere katılacağına bunları oyuncak haline getirip oynamaya başlayabiliyor. Bu da olumsuz etki olarak dile getirebiliriz." (Ö6)

"Velinin, öğretmenin yeterli olduğunu düşünüp, çocuğu için faydalı olacağına inanması, eğitim ve ögrretim için ögretmene güvenip destek olması çok önem arz eder. Bu sebeple eğitim ve ögretim materyallerini temin konusunda kendine göre değil çocuğun ihtiyacına yönelik öğretmenin belirlediklerinin temini gerekmektedir. Bu hem bağlarl kuvvetlendirir hem de çocuğun kendini bir bütünün parçası gibi hissetmesini sağlar. Oysaki biz ögretmenler, her yeni dönem uygun listeler hazırlarlz. İlk karşılaşttğımız engeller öğretmenim, büyük yoktu küçük aldım, çizgili bulamadım kareli aldım, o yoktu bunu aldım, pahaliydı исиzunu aldım ya da annem almaya gerek yok bunu kullan dedi gibi söylemler oluyor. Ben, öğretmenlik hayatım boyunca çallş̧tı̆ım yerler dolayısılla sinıf içi yaptıracağım etkinliklerde malzemeleri hep ben temin ettim. Hiçbir ögrencim kendini eksik hissedip çalışmalarda kendini yok saymasin diye..." (Ö1).

\section{Öğrencinin, Birinci Sınıfta Okula Devamını Sağlama Bakımından Veli- nin İlk Okuma Yazma Öğretim Sürecine Etkisi}

Öğrencinin, birinci sınıfta okula devamını sağlama bakımından velinin ilk okuma yazma öğretim sürecine etkisi alt sorusuna öğretmenlerin verdiği cevaplardan, ilk okuma yazma öğretiminde başarının sağlanmasında en önemli ögenin öğrencinin öğretime devamının sağlanması olduğu, bunu da temin edenin veli olduğu ve sürece etki eden unsurlardan en önemlilerden birisinin hatta birisinin bu olduğu bulgusuna ulaşılmıştır (f:12). Birkaç öğretmen görüşü şu şekildedir:

"Okula devamin sağlanmast öğrencinin geliş̧imi için çok önemlidir. Zamant iyi yöneten ve çocuğunun devamın sağlayan velinin çocuğu daha 
başarılı olabiliyor. Belki de bu süreçte velinin yapacağı en önemli katkı budur. Çokfazla devamsızlık yapan bir öğrenci sınıftaki öğrenme ortamını kaçırmakta ve geri kalmakta. Okuma yazmaya geçiş süresi uzamakta ve zorlaşmaktadır. Dolayısıyla okula devam konusunda titizlik gösteren veliler bunun geriye dönüşünü başarl olarak almaktadır." (Ö11)

"Eğitim-öğretim ve ilk okuma yazma ögrretimi açısından çok önemli ve en çok olumlu etki eden durum devamdır. Devamı sağlanan ögrencide, ögrenme kesintiye uğramadan devam ettiği için ögrenme süreci iyi şekilde sürmekte ve başarılı şekilde sonuçlanmaktadır. Devamı sağlayan da velidir." (Ö9)

"Devamsızlık kopuşa neden oluyor. Veli desteklerse diğerlerini yakallyor, sınıfta ögretmen de uğraşırsa yoksa geri kalabiliyor, velinin bakışı burada önemli. Çocuk, okuma yazma sürecinde aile desteği alırsa uyum sağllyor, süreci sağllklı bir şekilde sürdürüyor. Ancak yeterli destek göremezse kendi başına süreci götüremiyor ve başlıyor mazeret üretmeye (karnım ăgrıyor, ateşim çıktı, annemden ayrılmam...) Okula gelmek istemiyor. Devamsızlık da süreci olumsuz etkiliyor." (Ö7)

\section{Öğrencinin Ev Etkinliklerindeki Performansı Yönünden Velinin, İlk Okuma Yazma Öğretim Sürecine Etkisi}

Öğrencinin ev etkinliklerindeki performansı yönünden velinin, ilk okuma yazma öğretim sürecine etkisine yönelik araştırmanın alt sorusuna verilen öğretmen cevaplarına göre şu bulgulara ulaşılmıştır: Ev etkinliklerinde de görev yine velinin. Ev çalışmalarını planlı ve düzenli şekilde takip, bu konuda öğrencide sorumluluk bilincinin kazandırılması ve ev ortamında çalışmaları rahat bir şekilde gerçekleştirebilmesi için uygun zaman ve alanın oluşturulması velinin yapması gereken, beklenenlerdir. Öğrenciye ev etkinlikleri için verilenlerin çok ve kendi gücüyle, süreç içinde tamamlayamayacağı kadar fazla olması, velinin ev çalışmalarının önem ve etkisini bilmemesi, çocuğu ile bu konuda ilgilenmemesi ve destek vermemesi, zaman zaman veya sürekli çeşitli nedenlerle öğrencinin sorumluluğunda olan ve yapması gereken çalışmaları kendisinin yapması ile velinin eğitim ve öğretim düzeyi süreçte görülen olumsuzluklardır (f:6). Konuya ilişkin birkaç öğretmen görüşü şöyledir:

“Öğrencinin ödev takibinin yapılması ilk okuma yazma sürecinde önemlidir. Verilen ödevler pekiştirici olmal,; öğrenciyi bıktıran, küstüren ödevler olmamalıdır. Verilen birkaç sayfalık ödevler gelişi güzel yapılmakta beklenen sonucu vermemekte, bazen veliler tarafindan yapilmaktadır. Bunun yerine az ve öz ödev verilmeli veli de takibini yapmalıdır. Bu şekildeki çalışmada veli en büyük yardımcımız olur." (Ö4) 
"Veli her bakımdan çocuğun eğitim-ögretim sürecine etkin bir şekilde katılmasını sağlamada çok önemli bir rol üstlenmek zorundadır. Fakat genellikle veli bu süreçte kendini çok etkili görmediğinden tam anlamıyla üzerine düşeni yapamamaktadır. Genelde ögretmenlik hayatım boyunca ya hadi artı ödevini yap demekle kalan ya da dur ben yaparım, bak işte böyle yapllacak diyerek görevi kendi üstlenen çocuğu dışarıda bırakan velilerle çalıştım. Veli ev çalışmalarında çocuğa rehberlik ederek yapabilme güveni vermeli ve isteğini arttırmalıdır. Ama maalesef veli, istemsizce çocuğa kendini yetersiz hissettirerek yapamayacağl duygusunu veriyor. Olmadı yazamadın diyerek defalarca sildiren yazllar, arkadaşların bunları okuyor sen de okumalısın hadi artık bunu bunu yapacaksin söylemleri destekten ziyade engel oluşturuyor." (Ö1)

"Veli bir plan yapıp ve günü gününe uyguluyorsa ev çalışmalarında sorun yaşanmamakta, yaptırabilmekte. İlk harf gruplarının yazdırılma süreci genelde tüm veliler açısından zor bir süreç oluyor. Bu süreçte kendilerini yormak, uğraşmak istemeyen veliler çocukların ev çalışmalarını yapıp yolladığıyla da karşılaşabiliyoruz. Başlarda "kendi yazdı" demesine rağmen zaman geçtikçe işin vahametini anlayınca söylüyor ama iş işten geçmiş oluyor. Çocuğu toparlayıp sınıf seviyesine ulaştırmak bazen çok zaman alıyor." (Ö6)

"Öğrencinin ödevlerini bizzat yapıyorsa, ilgisiz davranıyorsa, uygun ortam hazırlamıyorsa, olumsuz etkisi var. İhtiyacı olduğunda öğrenciye destek oluyorsa, uygun ortam hazırllyorsa, ödevle ilgili düşüncelerini paylaşlyorsa, ilgilenip destek oluyorsa sürece mutlaka olumlu etkisi oluyor." (Ö7)

“Bu da çok önemli. Çocuklara evde ödevlerini yapmaları konusunda zaman, ortam yaratan ve ödev sorumluluğu konusunda destekleyen velilerin çocuklarının, planlı ve düzenli çalışma alışkanlıkları oluşturduğunu görüyorum." (Ö11)

\section{Sonuç, Tartışma ve Öneriler}

Velinin eğitim düzeyinin ilk okuma yazma öğretimi ve sürece etkisine ilişkin bulgular doğrultusunda; velinin, hatta çocuğun içinde yer aldığı aile üyelerinden birinin eğitim-öğretim düzeyinin yüksek olması çocuğun, bu önemli aşamada başarısını ve ilk okuma yazma öğretim sürecini olumlu yönde etkilemektedir. Bunun nedenini, velinin belli düzeyde öğrenim görmüş olmasının kazandırdığı olumlu bakışın olduğunu söyleyebiliriz. Ailenin, çocuğun okuma yazmada gelişim ve başarısı üzerindeki etkileri ile ilgili araştırmalarda, ailelerin eğitim öğretim seviyesine göre etkilerinin farklılaştığı, seviyeleri yüksek olan ailelerin çocuklarının okuma yazma becerilerine gösterdiği ilgi, katkı ve etkinin daha fazla olduğu saptanmıştır (Fitzgerald, Spiegel ve Cunningham, 1991). Tabii ki bu olumlu etki, öğretmeni de tüm öğrenim sürecinde 
olumlu etkileyecek, çalışmalarını kolaylaştıracak ve doğal olarak en büyük yardımcısı olacaktır. Yine araştırma bulgularından yola çıkarak velinin eğitim-öğretim seviyesinin yüksek olması, olumlu etki sağlamakta fakat bunun tersi durumlarda söz konusu olabilmektedir. Velinin, eğitim seviyesi düşük de olsa okulun, eğitim-öğretimin, bu dönemin önemini bilmesi, gerekliliğine inanması, ihtiyaç olarak görmesi, tutumu ile akademik anlamda olmasa da, çocuğunu güçlü şekilde motive ederek, gelen talep ve yönergelere uyup uygulayarak sürece ciddi olumlu destek sağlayabileceği sonuçlarına ulaşmak mümkündür. Alanyazında araştırma sonuçlarımız ile benzerlik gösteren şu çalışmalarda yer almaktadır: Erbasan ve Erbasan (2020) çalışmasında ailelerin eğitim düzeylerinin öğrenci başarısında oldukça belirleyici olduğu, ilk okuma yazma öğretiminde ailelerden kaynaklı sorunlardan birinin, ailenin eğitim seviyelerinin düşük olması ve hatta okuma yazma bilmemelerinin olduğu bunun ise eğitime bakışlarının olumsuz olmasına, önem verilmemesine neden olduğu sonuçlarına ulaşılmıştır. Benzer şekilde Akın (2016) öğrencilerin okuma, yazma ve okuduğunu anlama düzeylerini ebeveyn eğitimine göre incelediği çalışmasında, ebeveyn eğitimleri yükseldikçe çocukların okuma, yazma, okuduğunu anlama düzeylerinin arttığı sonucuna ulaşmıştır. Özcan ve Özcan (2016) çalışmalarında ise ilk okuma yazma sürecinde ailelerin eğitimsiz oluşu ve okula, çocuğa karşı ilgisiz kalmaları eğitim sürecinde büyük bir engel olarak öğretmenlerin karşısına çıkmakta olduğu sonucunu belirtmişlerdir. Konuya ilişki alanyazında benzer diğer çalışmalar görmek mümkündür (Babayiğit ve Erkuş, 2017; Çelik, Duran, Ferah, Kaya, Oymak ve Üredi, 2008; İflazoğlu-Saban ve Yiğit, 2011; Yiğit, 2009).

Öğretimde uygulanan yönteme göre ilk okuma yazma öğretim sürecine veli etkisi için elde edilen bulgulardan; yönteme ilişkin veli, bilgi, ilgi ve özelliklerinin ilk okuma yazma öğretim sürecine olumlu veya olumsuz yönde müdahil olması ve etkisi belirlenmiştir. Buna göre, velilerin bu süreçte, az da olsa öğretimde uygulanan yöntem-teknik hakkında fikir sahibi ise kendini konunun uzmanı hissederek katılım göstermekte, anlamıyor ise uzak kalıp izlemektedir. Okuma yazmayı nasıl öğrendiğini hatırlıyor ise o şekilde ve uzman olarak çocuğa öğretme çalışması içine girme, zaman zaman öğretmeni, uygulamayı eleştirmektedir. Uygulanan yöntem-tekniğin ne olduğunu bilmeme, bilmekte istememe gibi tutum ve davranışlar gösterdiklerini sonuçlarına ulaşı1mıştır. Günümüz velilerinin yaşları ve ilkokula başladıkları yıllar ile ilk okuma yazmayı öğrendikleri yönteme bakıldığında, bugünki öğretim yöntemteknik ve uygulamalarından uzak olduğu görülür. Dolayısı ile bu gününün 
velileri, çocukların öğrendiği ilk okuma yazma öğretimindeki yöntem-tekniklere ilişkin bilgilere sahip değillerdir. Veli, konuya ilgi duyup, ihtiyaç hissedip öğretmen ile iletişime geçip bilgilenmez ise bildiğini sandığ ş̧ekilde ve ısrarla katkı verecektir. Örneğin; a, b, c, ... şeklinde harfleri alfabetik sıra ile veya ne, ke, te, se, ... şeklinde harfleri okutma ve yazdırma çabası. Tabii bunlar, öğretmen ve öğrenci ile süreci olumsuz etkileyecek, gecikme, zorlaşma ve başarısız sonuçlanmasına neden olacaktır. İlk okuma ve yazma öğretimde veli, aile desteği şüphesiz çok önemli. Ancak, aile desteği kadar önemli olan diğer husus, verilen desteğin doğru olmasıdır. Zira, konuya ilişkin tüm alan çalışmalarında, ailelerin yanlış öğrenmelere sebep olmaları sık ve önemle vurgulanmaktadır. Konumuz ile ilgili ve sonuçlarımız ile örtüşen, alanyazında birçok çalışma yer almaktadır. Başar ve Tanış-Gürbüz (2020) ve Başar, Doğan, Şener, Karasu ve Yurttaş (2015), veliden kaynaklı ilk okuma yazma öğretimini olumsuz etkileyen sorunlardan birinin, metodolojik çatışma olduğunu belirlemiştir. Buna göre velilerin, kendi öğrendikleri yönteme göre evde destek sağladıkları, kendi öğrendikleri yönteme göre öğretim yapmaya çalışarak çocuklarda kavram karmaşası oluşturmaktadır. Erbasan ve Erbasan (2020) ise ailelerin sesleri yanlış öğrettiğini belirtmişlerdir. Benzer şekilde birçok çalışmada, ilk okuma yazma öğretiminde karşılaşılan sorunlar arasında veliden kaynaklanan sorunlar önemli yer almaktadır (Adıgüzel ve Karacabey, 2010; Babayiğit ve Erkuş, 2017; Bayat, 2014; Bektaş, 2013; Demir ve Ersöz, 2016; Uslu, 2014; Yiğit, 2009).

Öğrencinin, başarı-başarısızlık durumu ve motivasyonuna etki bakımından velinin, ilk okuma yazma öğretim sürecine etkisine ilişkin bulgulardan hareketle; süreçte veli etki ve tepkisinin genelde öğrenci başarısına göre olumlu, başarısızlığına göre olumsuz olduğu, öğrencinin motivasyonunun da bundan aynı şekilde etkilendiği sonucuna ulaşılmıştır. İlk okuma yazma öğretiminde öğrencinin yetersiz olması, geri kalması, başarısızlık göstermesini, veli ve/veya diğer aile üyeleri genel olarak olumsuz karşılamaktadır. Sert söz ve davranışlar ile tepki göstererek, en yakın arkadaşından başlayarak mukayese etmektedir. İlk okuma yazma öğrenmeyi basite alıp zaman zaman öğrenciyi küçük düşüren, rencide eden ifadeler ile küçümseyerek tepki gösterebilirler. Bu travma ile çocukta öğrenmeye, okula, öğretmene vb. karşı soğuma, motivasyonunu kaybetme, içine kapanma, okula gitmek, öğretmen ve arkadaşları ile karşılaşmak istememe durumları görülebilir. Bu durum çocuğun, gelecekte üst sınıf ve kademelerdeki başarısını da etkileyebilir. Tersine başarı gösteren çocuk, konuyu ve çocuğu önemseyen bilinçli veli tarafindan övülüp 
ödüllendirilebilir. Alanyazında araştırmanın sonuçlarıyla benzerlik gösteren çalışmalar bulunmaktadır. (Başar, Göncü ve Baran, 2021; Özcan 2014; Uslu 2014).

Velinin, öğretmen ile eğitim-öğretim sürecindeki iletişim-etkileşim ve öğrenci-öğretmen arasındaki ara bulucu rolü üstlenmesi bakımından ilk okuma yazma öğretim sürecine etkisine ilişkin bulgulardan, öğretmenlerin, öğretim sürecinde veliyi öğretimin önemli bir aktörü olarak gördükleri, öğretmen marifeti ile mutlaka öğretim sürecine dâhil edilmeleri gerektiği ve öğretimin, veli ile güçlü iletişim ve işbirliği içinde yürütülmesi gerektiği bunun, sürece yine oldukça olumlu ve doğrudan katkısı olacağı sonuçlarına ulaşılmıştır. Alanyazında yer alan araştırma sonuçlarından öğrenciler, öğretmenleri ve ilk ögretmenleri olan ebeveynleri arasındaki sık ve uzun süreli iletişim ve etkileşimlerin önemi vurgulanmaktadır (Farry-Thorna, Treimana ve Robinsba, 2020). Araştırmamızın bu sonucuyla örtüşen çalışmalardan bir diğerine göre, velilerin ilk okuma yazma öğretiminde öğretmenler ile yeterince iletişim ve işbirliği içinde olmamalarının süreci olumsuz etkilediği sonucuna ulaşılmıştır (Babayiğit ve Erkuş, 2017; Gündoğmuş, 2018).

Öğrencinin, okul dışında özellikle evde geçirdiği zamanın yönetimi konusunda velinin, ilk okuma yazma öğretim sürecine etkisine ilişkin ulaşılan bulgulardan; evde hazırlanan çalışma ortamı, çocuk üzerinde olumlu etkisi olacak denetim, çocuğun okul dışında kaliteli vakit geçirmesi, ihtiyaçları ile ilgilenilmesi, mutlu olması vb. imkân, zemin ve durumların veli tarafindan sağlanması, çocuğu ve dolayısı ile ilk okuma yazma öğretim sürecini olumlu yönde etkileyecektir sonucuna ulaşılmıştır. Örgün eğitim sistemi içinde okula devam eden öğrenciler günün 3/4'ü kadar önemli kısmını okul dışında, genelde evde ve veli ve/veya aile üyeleri ile birlikte geçirmektedir. Dolayısı ile bu sürecin verimli geçirilmesi ve nitelikli yönetimi önem taşımaktadır. Bu konuda veliye önemli görev ve sorumluluk düşmektedir. Okul dışında öğrencinin geçirdiği süreç ve faaliyetler hakkında öğretmenin bilgi sahibi olmasıda ayrıca önem taşımaktadır. McIntyre, Hulan ve Layne (2010) göre, öğretmenlerin, öğrencileri ve ailelerinin özellikle okul-dışı etkinlikleri hakkında bilgi sahibi olması, öğrencilerinin okuma-yazma öğrenmedeki gelişim ve başarısına katkı sağlamakta ve bunda çok önemli rol oynamaktadır. Yine, araştırmamız bulgu ve sonuçları ile benzerlik gösteren Satır, (1996) araştırmasında; çocuğuna yakın ilgi gösteren, çalışma ortamını düzenleyen ve planlayan, başarısını övücü sözlerle destekleyen, başarısızlığında onu çalışırsan başarılı olursun sözleriyle 
yüreklendiren anne-babaların çocuklarının akademik başarılarının yüksek olduğu sonuçlarına ulaşılmıştır. Araştırma sonuçlarımız ile benzerlik gösteren diğer çalışma sonucuna göre ebeveynlerin, çocuklarının okuma yazmadaki gelişimleri için evlerinde sağladığ 1 ortam ve imkanlar ilkokulda, öğrencilerin okuma yazma başarısındaki bireysel farklı1ıkları anlamak için önemli bir yer sahiptir (Evans ve Hulak, 2018).

İlk okuma yazma öğretimi için gerekli araç-gereçler ile öğretmenin, öğretim için kaynak talebine yaklaşım ve temini yönünden velinin, ilk okuma yazma sürecine etkisi ile ilgili olarak şu sonuçlara ulaşmak mümkündür: İlk okuma yazma öğretiminde, nitelikli araç-gereç kullanımı nitelikli ürün bakımından önemlidir ve başarı ile öğretmen, öğrencinin motivasyonunu sağlayan, artıran unsurdur. Öğretmenler, Milli Eğitim Bakanlı̆̆ı'nın öğretim için temin ettiği ve öğretimde kullanılan temel kaynakları yetersiz ve niteliksiz bulmaktadır. Araç-gereç ve yardımcı kaynak talebi konusunda genel olarak veliler, öğretmen istiyor ise mutlaka önemli ve gereklidir, çocuğuna süreçte yarar sağlayacaktır düşünceleri ile olumlu yaklaşmakta ve öğretmene güven duymakta ve sürece destek olma gayreti göstermektedirler. Ancak, temin ve nitelikte özen göstermemektedirler. Alanyazında araştırma sonuçlarımızı destekleyen birçok çalışma yer almaktdır. Ihmeideha ve Al-Maadadib (2020)'e göre göre, genel olarak aile, çocuklara kitap okuma, çocuklarla yazma, çocuklara okuma yazma materyalleri sağlamak vb. ile okuma yazama ilgili uygulamalara dâhil olduğunda çocukların öğrenimi geliştirilmekte ve başarıları artmaktadır. Araştırma bulgu ve sonuçlarını destekleyen Erbasan ve Erbasan (2020) çalışmada, öğretmenlerin tamamı, kullanılan ders kitaplarını yeterli bulmaması düşündürücü bir sonucuna ulaşıldığı belirtilmiştir. Bir diğer çalışmada, ilk okuma yazma öğretimi kitaplarında yeterince etkinlik yer almadığ1 ve kitaplarının yetersiz kaldığı belirtilmektedir (Babayiğit ve Erkuş, 2017). Bektaş (2007) çalışmasında öğretmenlerin büyük çoğunluğunun kaynak kitabı yetersiz bulduğunu tespit etmiştir. Avcı ve Şahin (2016), öğretmenlerin büyük çoğunluğunun, kaynak kitapta sözcüklerin hecelerine yanlış ayrılmasının sonucu öğrencilerde okuma bozukluğunun görüldüğünü belirlemiştir. Özcan ve Özcan (2016) ise araştırma bulgularından hareketle, basılı materyalin öğretim sürecini desteklemediği sonucuna ulaşmışlardır. Benzer çalışmalarda (Adıgüzel ve Karacabey, 2010; Babayiğit ve Erkuş, 2017; Polat, 2017) çalışmamız ile örtüşen bulgu ve sonuçlara ulaşıldığı görülmektedir. Konumuz ile ilişkili alan çalışmalarının önemli kısmında çalışmamız bulgu ve sonuçlarının doğrultusunda velilerin, ilk okuma yazma öğretimine karşı kayıtsız kaldığı ve 
ilgili materyalleri temin etmediği bulgu ile sonuçlarına ulaşıldığı görülmektedir (Cerit, Akgün, Yıldız ve Soysal, 2014; Demir ve Ersöz, 2016; Korkmaz, 2006; Ünüvar, 2005).

Öğrencinin, birinci sınıfta okula devamını sağlama bakımından velinin, ilk okuma yazma öğretim sürecine etkisine ilişkin bulgulardan hareketle şu sonuçlara ulaşmak mümkündür: İlk okuma yazma öğretiminde başarının sağlanmasında, sürece etki eden unsurlardan en önemlisi hatta birincisi; temin, kontrol ve sorumluluğu velide olan, öğrencinin öğretime devamının sağlanmasıdır. İlk okuma yazma öğretim sürecinde etkisi en yüksek, veli sorumluluğundaki önemli etmenlerden birinin, öğrencinin okula devamının sağlanması olduğunu ifade edebiliriz. Bu öğrenci motivasyonu ve başarısı açısından son derece önemlidir. İlk okuma yazma öğretim süreci yoğun geçen ve birbirine bağlı etkinliklerden oluşur ve devamsızlığa tahammül yoktur. Bu süreçte, hele hele hassas ilgi ve takip göstermeyen veli ile devamsızlıkta çok ciddi ve telafisi mümkün olmayan kayıplar yaşanabilir. Öğrenci, kopmalar yaşar, geri kalır, motivasyonu bozulur ve başarısızlığa doğru hızla sürüklenir. Ayrıca, tutarl1-tutarsız türlü gerekçeler ile okula gitmek istemeyen öğrenci, birde gitmemeyi başarır ise çok lezzetli tat bırakır ve bunu sürekli hale getirmek için üst çaba gösterir. Bu süreç öğretmen bakımından da ayrı öneme sahiptir hiç şüphesiz. Zira, başarının mimarı öğretmenlerdir. Öğretmen, öğretimde geri kalan, kopmalar yaşayan ve düzeyleri farklılaşan öğrencilere ayrı ayrı zaman ayırmak, birebir ilgilenmek, rehberlikte bulunmak durumunda kalır ki bu, hiç de istenen bir durum değildir. Demir ve Ersöz (2016) çalışmalarında velilerin, çocuklarının okumaya geçmesi konusunda aceleci davranmaları, öğrencinin gelişim düzeyini anlayamamaları, ses yerine harf öğretimine yönelmeleri, öğrenciyi çalıştırma konusunda ilgisizlikleri, gerekli materyalleri temin etmeme, öğrencinin devamsızlığına kayıtsız kalma şeklinde çalışmamız sonuçları ile benzerlik gösteren sonuçlara ulaşı1mıştır.

Öğrencinin ev etkinliklerindeki performansı yönünden velinin, ilk okuma yazma öğretim sürecine etkisine yönelik araştırmanın bulgularından hareketle şu sonuçlara ulaşılabilir: Ev etkinliklerinde de görev yine velinindir. Ev çalışmalarını planlı ve düzenli şekilde takip, bu konuda öğrencide sorumluluk bilincinin kazandırılması ve ev ortamında çalışmaları rahat bir şekilde gerçekleştirebilmesi için uygun zaman ve alanın oluşturulması velinin yapması gereken, beklenenlerdir. Öğrenciye, ev etkinlikleri için verilenlerin çok ve kendi gücüyle, süreç içinde tamamlayamayacağı kadar fazla olması, velinin 
ev çalışmalarının önem ve etkisini bilmemesi, çocuğu ile bu konuda ilgilenmemesi ve destek vermemesi, zaman zaman veya sürekli çeşitli nedenlerle öğrencinin sorumluluğunda olan ve yapması gerek çalışmaları kendisinin yapması ile velinin eğitim-öğretim düzeyi süreçte görülen olumsuzluklardır. Araştırmamız bulgu ve sonuçları ile örtüşen Aslan ve Altınova (2019) çalışmalarında, eğitim seviyesi daha yüksek olan velilerin bu sürece olan katkısı olumlu olmakta iken eğitim seviyesi düşük bazı velilerin bu sürece olumsuz etki ettiği ve bazı velilerin verilen ödevi bizzat yaptığı sonuçları belirtilmiştir.

İlk okuma yazma öğretimine veli etkisini konu alan çalışmamızda ulaş1lan sonuçlara dayalı olarak şu öneriler geliştirilmiştir:

1. Veli toplantıları yoluyla veliler, ilk okuma yazma sürecine etkin bir şekilde dâhil edilebilir. Yapılan veli toplantılarında öğretmenler velileri süreçle ilgili bilgilendirebilir.

2. Velilerin ilk okuma yazma sürecinde öğrencilerin, kendi becerilerini geliştirmeye yönelik destekleri sağlanmalıdır.

3. Veliye, öğrencilerin her birinin birer değer olduğu, farklı öğrenme biçim, hız, süre ve özelliklerinin olduğu, birbirleri ile mukayese edilmelerinin yanlışı velilere anlatılmalı bunun için rehber öğretmenlerden destek alınmalıdır.

4. İlk okuma yazma sürecinin başarısı açısından öğretmen-veli-öğrenci iletişim ve etkileşimi güçlendirilmelidir. Bunun için dijital ortamlar etkin olarak kullanılabilir

5. Okul dışındaki zamanlarda da veli desteği etkin olarak kullanılabilir. Veli ile öğretmenin öğrenciyi aynı anda takip edebildiği dijital bir platform oluşturulabilir.

6. Araştırma bulgu ve sonuçlarına göre öğretmenler Milli Eğitim Bakanlığı'nın temin edip öğretimde kullanılmasını istediği ders kitabını yetersiz görmüşler ve özel yayınevlerinin hazırlamış oldukları yardımcı kaynaklarla desteklenmesi gerektiğini belirtmişlerdir. Bu nedenle, ilk okuma yazma öğretiminde temel ders aracı olan kitaplar EBA platformunda olduğu gibi çok daha nitelikli hale getirilmeli ve yüz yüze eğitimde de öğretim, aynı şekilde elektronik ortamda hazırlanmış nitelikli etkinliklerle desteklenmelidir. 


\section{Kaynakça}

Adıgüzel, A. ve Karacabey, M. F. (2010). Sınıf öğretmenlerinin ilk okuma yazma öğretiminde karşılaştıkları sorunlar. E-Journal of New World Sciences Academy, 5(2), 1382-1394.

Aslan, M. ve Altınova, N. (2019). Birinci sınıf Türkçe (ilkokuma yazma) öğretim programının değerlendirilmesi. Adlyaman Üniversitesi Sosyal Bilimler Enstitüsü Dergisi, 12(32), 31-75.

Doi: 10.14520/adyusbd.490598

Avc1, Y. E. ve Şahin, M. (2016). Ses temelli okuma-yazma öğretiminde sınıf öğretmenlerinin karşılaştığı sorunların incelenmesi. Siirt Üniversitesi Sosyal Bilimler Enstitüsü Dergisi, 4(6-7), 59-79.

Babayiğit, Ö. ve Erkuş, B. (2017). İlk okuma yazma öğretimi sürecinde sorunlar ve çözüm önerileri. Erzincan Üniversitesi Eğitim Fakültesi Dergisi, 19(2), 271284.

Başar, M., Doğan, C., Şener, N., Karasu, M. ve Yurttaş, R. (2015). İlk okuma yazma sürecine açık hece ya da kapalı hece ile başlamak. International Journal of Language Academy, 3-4(9), 442-452.

Doi: $10.18033 /$ ijla.340

Başar, M., Göncü, A. ve Baran, M. S. (2021). Öğrenme güçlüğü yaşayan öğrencilerin eğitiminde bir eylem araştırması. Pamukkale Üniversitesi Eğitim Fakültesi Dergisi, 51, 327-348.

Doi:10.9779.pauefd.687030

Başar, M. ve Tanış-Gürbüz, H. M. (2020). İlk okuma ve yazma öğretiminde karşılaş1lan sorunlar ve çözüm önerileri. Okuma Yazma Eğitimi Araştırmaları, 8(1), $1-20$.

Bayat, S. (2014). Sınıf öğretmenlerinin ilkokuma yazma programının uygulanmasında karşılaştıkları güçlüklere ilişkin görüşleri. Illköğretim Online, 13(3), 759775 .

Bektaş, A. (2007). Ses temelli cümle yöntemiyle gerçekleştirilen ilk okuma-yazma öğretiminin değerlendirilmesi. Yayımlanmamış yüksek lisans tezi, Çukurova Üniversitesi Sosyal Bilimler Enstitüsü.

Bektaş, E. (2013). Illkokuma yazma öğretiminde karşılaşılan sorunlar ve çözüm yollarının karma yöntem aracılığıyla incelenmesi. Yayımlanmamış yüksek lisans tezi, Karadeniz Teknik Üniversitesi Eğitim Bilimleri Enstitüsü.

Boody, M. R. (2003). Encouraging literacy for personal development. Reading Improvement, 40(3), 99-103.

Burns, C. P., Roe B. D. ve Ross E. P. (1992). Teaching reading in today's elementary scchools. Boston: Houghton Mifflin Company.

Büyüköztürk, Ş., Kılıç Çakmak, E., Akgün, Ö. E., Karadeniz, Ş. ve Demirel, F. (2012). Bilimsel araştırma yöntemleri (12. bask1). Ankara: Pegem Akademi.

Cerit, Y., Akgün, N., Yıldız, K. ve Soysal, M. R. (2014). Yeni eğitim sisteminin $(4+4+4)$ uygulanmasında yaşanan sorunlar ve çözüm önerileri (Bolu İl Örneği). Eğitim Bilimleri Araştırmaları Dergisi, 4(1), 59-82.

Çelenk, S. (2003). İlkokuma-yazma öğretiminde kuluçka dönemi. Ankara Üniversitesi Eğitim Fakültesi Dergisi, 36(1-2), 75-80. 
Demir, O. ve Ersöz, Y. (2016). 4+4+4 Eğitim sistemi kapsamında sınıf öğretmenlerinin ilkokuma ve yazma eğitiminde yaşadıkları güçlüklerin değerlendirilmesi. Turkish Online Journal of Qualitative Inquiry, 7(1), 1-27.

Doi: 10.17569/tojqi.90651

Erbasan, Ö. ve Erbasan, Ü. (2020). Sınıf öğretmenlerinin ilk okuma yazma öğretimi sürecinde karşılaştı̆̆ı sorunlar. Ana Dili Eğitimi Dergisi, 8(1), 113-125.

Evans, M. A. ve Hulak, L. (2018). Learning to read at home: Kindergarten children's report in relation toobserved parent behaviour. Early Childhood Research Quarterly, 50(1), 38-45.

Doi: 10.1016/j.ecresq.2018.09.010

Farry-Thorna, M., Treimana, R. ve Robinsba, S. (2020). Letter teaching in parentchild conversations. Early Childhood Research Quarterly, 53, 161-170.

Doi: $10.1016 /$ j.ecresq.2020.03.008

Fitzgerald, J., Spiegel, D. L. ve Cunningham, J. W. (1991). The relationship between parental literacy level and perceptions of emergent literacy. Journal of Reading Behavior, 23(2), 191-214.

Güler, A., Halıcıoğlu, M. ve Taşğın, S. (2015). Sosyal bilimlerde nitel araştırma. Ankara: Seçkin Yayıncılık.

Gündoğmuş, H. D. (2018). The difficulties experienced by teachers in the process of primary reading and writing instruction and their solution offers for eliminating these difficulties. Universal Journal of Educational Research, 6(2), 333339.

Güneş, F. (1997). Okuma yazma öğretimi ve beyin teknolojisi. Ankara: Ocak Yayınlar1.

Ihmeideha, F. ve Al-Maadadib, F. (2020). The effect of family literacy programs on the development of children's earlyliteracy in kindergarten settings. Children and Youth Services Review, 118, 1-7.

Doi: 10.1016/j.childyouth.2020.105462

Isaacs, B. (2012). Understanding the Montessori approach, early years education in practice. London: Routeldge.

İflazoğlu-Saban, A. ve Yiğit, V. (2011). Ses temelli cümle yöntemi ile ilkokuma yazma öğretim sürecinde karşılaşılan güçlükler ve bu güçlüklerle başetme stratejilerinin belirlenmesi: (Şırnak ili örneği). Ç. Ü. Sosyal Bilimler Enstitüsü Dergisi, 20(3), 319-342.

Korkmaz, İ. (2006). Yeni ilköğretim birinci sınıf programının öğretmenler tarafından değerlendirilmesi. S.Ü. Sosyal Bilimler Enstitüsü Dergisi, 16, 419-432.

McIntyre, E., Hulan, N. ve Layne, V. (2010). Reading instruction for diverse classrooms: Research-based, culturally responsive practice. New York: Guilford Press.

Neuman, L. W. (2007). Toplumsal araştırma yöntemleri: Nitel ve nicel yaklaşımlar. (S. Özge, Çev.). İstanbul: Yayın Odası. (Orijinal çalışma basım tarihi 2016.)

Ogano, J. A. (2012). Teaching learners with reading and writing problems in the classroom: an interview study with teachers in Norwegian schools. Yayımlanmamış yüksek lisans tezi, Master's Dissertation Department of Special Needs Education Faculty of Educational Sciences University of Oslo. 
Özcan, A. F. ve Özcan, A. O. (2016). İlk okuma yazma öğrenmede çocukların yaşadıkları güçlükler, nedenleri ve çözüm önerileri: nitel bir araştırma. $\dot{I} G \ddot{U} S B D$, 3(1), 69-103.

Polat, H. (2017). İlk okuma-yazma öğretiminde kullanılan yöntem ve kaynaklara ilişkin öğretmen görüşleri (Ankara/Yenimahalle örneği). International Journal of Languages' Education and Teaching, 5(2), 166-186.

Sağırlı, M. (2019). İlkokuma yazma öğretiminin önemi, amacı ve birinci sınıf öğretmenliği. Ö. Yılar, (Ed.), Illkokuma ve yazma öğretimi içinde (1-30). Ankara: Pegem Akademi.

Sarığlu, S. (2016). İlkokul birinci sınıf öğrencilerinin okuma, yazma ve okuduğunu anlama düzeylerinin farklı değişkenler açısından incelenmesi. Yayımlanmamış yüksek lisans tezi, Düzce Üniversitesi Sosyal Bilimler Enstitüsü, Düzce.

Satır, S. (1996). Özel Tevfik Fikret Lisesi öğrencilerinin akademik başarılarıyla ilgili anne-baba davranışları ve akademik başarıyı artırmaya yönelik anne-baba eğitim gereksinmelerinin belirlenmesi. Yayımlanmamış yüksek lisans tezi, Ankara Üniversitesi Sosyal Bilimler Enstitüsü, Ankara.

Strickland, D. S. ve Riley-Ayers, S. (2006). Early literacy: Policy and practice in the preschool years. Preschool Policy Brief, 10, 1-12.

Şenel, G. H. (2004). Öğretmenlerin ilkokuma - yazma öğretiminde tercih ettikleri yöntemler. Illkögretim-Online, 3(2), 48-53.

Uslu, S. (2014). Yenilenen ilkokul basamağında gerçekleştirilen okuma yazma öğretim sürecine ilişkin öğretmen görüşleri. Yayımlanmamış Yüksek Lisans Tezi. Çanakkale Onsekiz Mart Üniversitesi Eğitim Bilimleri Enstitüsü, Çanakkale.

Ünüvar, P. (2005, Kasım). Burdur ili ilkögretim okullarında ilkokuma ve yazma öğretiminde karşılaşılan sorunlar. I. Burdur Sempozyumu'nda sunulan bildiri, Burdur.

Yıldırım, A. ve Şimşek, H. (2018). Sosyal bilimlerde nitel araştırma yöntemleri (11. bask1). Ankara: Seçkin Yayıncılık.

Yiğit, V. (2009). Ses temelli cümle yöntemi ile ilk okuma yazma öğretim sürecinde karşılaşılan güçlükler ve bu güçlüklerle baş etme stratejilerinin belirlenmesi; (Şırnak ili örneği). Yayımlanmamış yüksek lisans tezi, Çukurova Üniversitesi Sosyal Bilimler Enstitüsü. 